\title{
THE IMPORTANCE OF HIGH - TECH COMPANIES FOR EU ECONOMY - OVERVIEW AND THE EU GRAND STRATEGIES PERSPECTIVE
}

\author{
Alenka Pandiloska Jurak \\ Faculty of Information Studies Novo mesto, Slovenia \\ E-mail: alenka.pandiloska@fis.unm.si
}

\begin{abstract}
In the context of economic globalization, technology is a key factor in boosting growth and competitiveness in the business world. Technologically intensive companies have more innovation, gain new markets, use available resources more productively, and generally offer more to the people they employ. Europe spends less on R\&D, compared to the US and Japan, mainly due to lower levels of private investment. The lower share of HTC in the EU is the reason for half of the EU's lag behind the US. The aim of this paper is therefore to present the importance of high - tech companies for EU economy and to evaluate the steering of Europe 2020 grand strategies towards active support of HTCs and estimate, how Europe 2030 strategies will continue the effort of boosting EU economy.
\end{abstract}

Key words: high - tech companies, EU Grand strategies, policy, innovation, research and development, business ecosystem prerequisites

\section{Introduction}

Technology is a key driver in the global economy (Morrison 2002, 279). In the context of economic globalization, technology is a key factor in boosting growth and competitiveness in the business world. This is also one of the key aspects of European grand strategies, aiming to achieve smart, sustainable and includive growth (Rončević 2019; Makarovič et al. 2014). Technologically intensive companies have more innovation, gain new markets, use available resources more productively, and generally offer more to the people they employ. High-tech companies are the ones whose products are expanding the fastest in international trade, and their dynamics help to improve efficiency in other sectors (Hatzichronoglou 1997, 4). The lower share of VTP in the EU is the reason for half of the EU's lag behind the US (ibid.).

The OECD Secretariat has identified the methods used to classify sectors and products by level of technology and has drawn up two lists: one for 
activities (sectoral approach) and the other for products (product approach). The data used in compiling the list by activity are based on the International Standard Classification of Industrial Activities, ISIC Rev 2. The new classification covers only the manufacturing industry. They set the intensity of research and development (R\&D) as the only criterion, based on which they identified four groups: high, medium-high, medium-low and low technologies (Hatzichronoglou 1997, 4-5). The product-by-product approach has been developed to supplement the list by activity and provides a more appropriate tool for analyzing international trade. It is based on the Standard International Trade Classification, SITC Rev 3 (Hatzichronoglou 1997, 4).

We distinguish between two types of technologies (see European Commission, Eurostat 2014), namely production and knowledge-based technology. Eurostat uses aggregation of industrial production according to technological complexity. It identifies four levels: high technology, mediumhigh, medium-low and low technology 1 . Following a similar procedure as for manufacturing, Eurostat on subdividing the services sector as knowledgebased services and services based on the lower level of knowledge. Aggregation of services is done only at level 2 (European Commission, Eurostat 2014). We are pointing out the classification due to its strict differentiation and due to the general assumption, what high technology is. Companies might be using high-tech products and procedures, which does not qualify them high-tech companies.

\section{The importance of the high-tech sector for the economy}

In the global competition for competitiveness (European Commission, Eurostat 2016a), the creation, exploitation and commercialization of new technologies are essential. In the context of economic globalization, technology is a key factor in promoting growth and competitiveness in the business world. The high-tech sector and enterprises are a key driver of economic growth and productivity and generally provide high added value

${ }^{1}$ High technology (products): Manufacture of pharmaceutical raw materials and preparations, Manufacture of computer, electronic and optical products, Manufacture of aircraft and spacecraft.

Medium-high technology (products): Manufacture of chemicals and chemical products, Manufacture of weapons and ammunition, Manufacture of electrical equipment, Manufacture of other machinery and equipment, Manufacture of motor vehicles, trailers and semi-trailers, Manufacture of other transport equipment, Ship and boat construction, except Manufacture of aircraft and spacecraft, Manufacture of medical instruments, appliances and supplies. 
and well-paid jobs. Investment in research, development, innovation and skills is therefore a key policy area for the EU, as it is essential for economic growth and the development of a knowledge-based economy (ibid.).

A study of a cluster of high-tech companies in Montana (USA) (Barkey et al. 2015) showed that the growth of high-tech companies by almost every criterion is outpacing other sectors of the economy in the country, both in terms of employment and expected revenues. Fold growth rate throughout the country. Employment in high-tech companies is paid much better than elsewhere in the economy. On average, high-tech companies are smaller, younger and more growth-oriented. High-tech companies that are members of the Montana cluster raised wage rates by $7 \%$ in 2013, which is significantly more than the $1.4 \%$ growth rate of real wages in the private sector. Cluster members planned more than 400 new jobs in 2015 or a $15 \%$ increase, which represents a much higher growth in the number of jobs compared to the economy as a whole (ibid.).

The dynamics of the high-tech sector can help to improve efficiency also in other sectors (European Commission, Eurostat 2016). The results of a study (Tongbin et al. 2015) on the effects of the high-tech industry on various areas of the Chinese national economy show that the high-tech industry has the most direct and significant impact on the secondary industry (mining, energy, industry, construction, $\mathrm{A} / \mathrm{N}$ ) it can have exceptional and strong effects on the growth of secondary industry production, but it can show itself in a longer time lag. The effects on the tertiary industry (services, transport, trade, tourism, A/N) cannot yet be shown or they are relatively weak, but their permeability is rapid. It was found that the impact of high technologies on capital accumulation in both the secondary and tertiary sectors has increased significantly (ibid.).

Certain specificities in the high-tech sector cannot be detected in other sectors. One of these is the role of the entrepreneur's personal capital in operating in high- and low-tech demanding industries. In Japan (Kato and Hunjo 2015), the survival factors of start-ups were studied, where exit routes were also considered, thus distinguishing between errors (eg. bankruptcy) and other forms of "failure" (eg. voluntary liquidation, merger, etc.). The results showed that entrepreneurs' personal capital, measured as education, and is important in reducing the likelihood of bankruptcy in high-tech sectors, but this is not the case for less-developed sectors. In addition, they found that in companies run by entrepreneurs with a high level of personal capital, mergers are likely to occur, especially in the high-tech sectors. They also found that entrepreneurs coming from the natural sciences are less in favour 
of mergers than those coming from the social sciences, especially in less developed sectors (ibid.).

Intellectual capital is relevant to each sector. It is of particular importance for maintaining a competitive advantage (Hsu and Chang 2011) in a fastgrowing high-tech industry. Taiwan's high-tech industry has high added value, surpassing the global industry over the past decade. It seeks to expand its leadership in high technology by creating higher-value silicon intellectual property and increasing reuse. Since 2002, the Taiwan Stock Exchange has even gradually established a system of information disclosure and transparent ranking of all companies. The classification system assumes that more voluntarily disclosed information about companies could increase investor monitoring, reduce risk assessment and improve governance. However, high-tech companies are concerned that disclosure of intellectual capital could put companies at a competitive disadvantage. They have shown that the risk of this is less if these disclosures are voluntary (ibid.).

The high-tech industry is expanding most strongly in international trade (European Commission, Eurostat 2016). Graph 1 shows that High technology exports as in \% of manufactured exports reach over $15 \%$ in 2018, leading by China with over 31\%. The Graph also show a drop in 2016 in the EU, OECD, USA and Israel. Since 2018 are the latest available data it will be interesting to see, how the current COVID 19 crisis affected the export.

Graph 1: High technology exports (\% of manufactured exports)

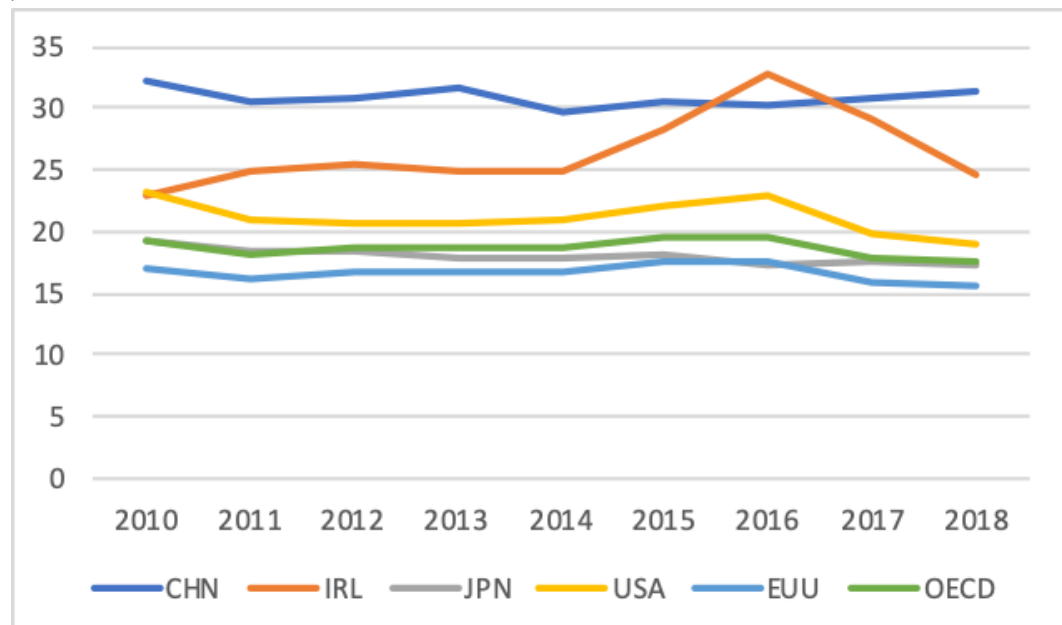

Source: World Development Indicators, Last Updated: 09/08/2020 
The connection between the possibilities of survival of high-tech start-ups in connection with a foreign market is also interesting. In India (Krishna, Subrahmanya and Bala 2015), a study was conducted based on 45 high - tech start-ups based in different locations in India, comparing transnational startups and those operating locally. The results of the study showed that transnational high-tech start-ups have a greater chance of survival compared to local high-tech companies. In addition, it was found that graduates of technical fields who gained entrepreneurial experience and early funding were also more likely to achieve the survival of their high - tech start-ups. The study was designed to reveal the forms and types of factors that need to be examined to enable a vibrant start-up ecosystem in the region. It is aimed at policymakers and investors who focus on emerging economies (ibid.). One of the more general objectives of economic policy is to provide quality jobs (Adkisson and Saucedo, 2010). In recent decades, high-tech jobs have been adopted as synonymous with high-quality jobs, and political efforts in this area have increased (Adkisson 2015).

\section{The importance of the economic crisis and other factors for the high-tech sector}

As a direct cause (Mrak and Rant 2011) of the current global economic crisis, we understand the collapse of the real estate market in the US in 2007. Due to the growing share of outstanding loans, there were severe liquidity problems in the US financial sector. By 2008, financial institutions around the world were affected. Wider, systemic causes, which relate in particular to the functioning of the international financial system and the increase in the balance of payments imbalances (ibid.). Also served as a precondition for the increase in risks and asymmetric information in the international financial environment.

Despite the belief that the European economy will remain largely unaffected (Štiblar 2008, 95), the economic crisis has gradually begun to manifest itself in Europe as well. The first signs appeared in 2008, when due to the interconnectedness of international financial centres and excessive investment in the US real estate market, the financial system, which included banks, insurance companies and central banks of European countries, was severely exposed to shocks in the subprime mortgage square. The problems were particularly pronounced in the United Kingdom, Luxembourg and Ireland. They were hit by a more pronounced real estate crisis, while Iceland and Switzerland faced mainly a banking crisis (ibid.). 
The economic crisis (Berkmen et al. 2012) has had a different impact between developing countries and emerging markets. Even a small set of variables can explain the larger share of differences in the impact of growth. Countries with more advantage in the domestic financial system, stronger credit growth and more short-term debt mostly feel the greater impact of the crisis on economic activity, although the relative importance of these factors varies between countries. In emerging markets, it helps the trade financial channel. Exchange rate flexibility has helped mitigate the impact of the shock, especially for emerging markets. There is also evidence that the crisis had a smaller impact on countries that had a stronger fiscal position before the crisis. However, we find little evidence for the importance of other policy variables (ibid.).

The consequences of the economic crisis (see Svetličič 2015, 185-202) and dramatic changes in the world economy are reflected in the reduction of the share of Western Europe in world GDP to $20 \%$.

The economic recovery (Sandua and Ciocanel 2014) and the restoration of sustainable economic growth in the EU are largely driven by exports, especially in the high-tech sector. Through theoretical and empirical approaches, various authors have proven the relationship between some indicators of innovation performance and the volume and implementation of high-tech exports (ibid.). Endogenous theories of growth explain the productivity growth of the new economy by drawing attention to technological innovations created through Research and Development (henceforth R\&D) (Karahan 2015). There is a causal link (Sandua and Ciocanel 2014) between the volume of R\&D expenditure, employment in the high-tech sector and international trade alliances, and the share of exports of high-tech companies to the EU. There is also a positive correlation between the total volume of R\&D research expenditure and the level of high-tech exports. Data vary between EU countries. However, the impact of private expenditure on research and development is stronger than that of public expenditure (see also Chart 2.5). Current European and national policies are increasing the intensity of R\&D funding. The goal is to raise the average level of EU R\&D expenditure to 3\% of GDP and to raise the average EU private expenditure to $2 \%$ of GDP, which can significantly increase exports and competitiveness (ibid.).

A survey (Karahan 2015), made based on European countries, sought to define the relationship between business expenditure on $R \& D$ and productivity growth through an indication of the role of transformation in the manufacturing sector towards high-tech manufacturing. Empirical findings show that there is a strong causality between the increase in the intensity of 
business entities in the field of $R \& D$ and the growing share of high and medium high technology production. The study finds that $R \& D$ expenditure by businesses is one of the main sources of improvements in high-valueadded technological production capacity in Europe. From a policy perspective, the implication of these results is important. Public policies should create appropriate incentives for private investment in R\&D to ensure a transformation in the manufacturing sector towards high-tech specifications and further growth in an innovation-dependent economy (Karahan 2015).

The positive correlation between R\&D investment (Wanga, Yub and Liub 2013) and economic growth is also evidenced by comparative empirical data from 23 OECD member countries and Taiwan. The impacts of $R \& D$ expenditure in the high-tech sector are heterogeneous across income levels per capita (ibid.).

Furthermore, the research analyzed the factors of innovation performance of the high-tech sector in EU countries. Innovation performance is assessed through the application of patents, granted patents and trademark applications. The findings show that the number of employees in the hightech industry has a positive effect on the number of patents, while R\&D expenditure (per capita) has a negative impact. Other factors, such as education expenditure, government $R \& D$ expenditure, economic development, the number of science and technology employees and the level of exports, do not affect innovation performance in the high-tech industry. In the case of brand application, the situation is different, namely significant expenditures on R\&D and human resources employed in science and technology. While exports have a positive impact on outgoing innovation, economic development has a negative effect. However, it should be noted that the data used are robust and have some shortcomings in terms of unavailability of data for all countries, the method of weighting, etc. (Baesu et al. 2015).

As a success story, however, we can present the case of Israel. In Israel, too, the high-tech industry has a major impact on the overall economy (Tamar 2011). Between the years 1970 and 2000 due to the success of the high-tech sector to the transformation of the Israeli economy. The success of the sector is due to the support of the Israeli government, which has promoted civilian research and industrial development (Berry and Grayeff 2009). As a result (Tamar 2011), the Israeli economy overcame the recession relatively well in 2008. Their economy is largely dependent on small high-tech multinationals (they have also implemented other measures, such as increasing foreign direct investment, etc.), while macroeconomic indicators showed good 
results compared to the EU and the US. The reasons for this are based on the predominance of high-tech companies, "born global" companies and small high-tech multinationals. Business strategies based on (1) size and flexibility (2) focused and tailored, and (3) innovation and globality have allowed small high-tech multinationals to continue to grow and achieve their goals despite the great recession (ibid.).

However, changes in the technological structure of production in the direction of the high-tech sector do not in themselves automatically lead to an improvement in labour productivity (see Šipilova 2015). They can also be a trap for economically less developed regions, which tend to increase the presence of the high-tech sector in the production structure but are unable to achieve the desired improvements and economic growth. Using structural changes and a specialization index and a shift-share analysis technique, the impact of structural changes on economic growth in the manufacturing sector was analyzed in the Latvian regions. The empirical results of the research emphasize that those Latvian regions that opt for a more technologically advanced production structure and pay less attention to improving labour productivity find themselves in a situation where strengthening specialization in the high technology sector is not reflected in regional economic growth (ibid.).

If we noted above the positive effect of investment in R\&D in connection with the high-tech sector, it is also necessary to point out bad practices from which much can be learned. This was shown by the results of a survey assessing the effectiveness of national high-tech zones in China after the financial crisis (Baia, Yanb and Chiu 2015). They found that the efficiency of both the high-tech manufacturing and R\&D sectors is low, partly because the links between the sectors are weak and transfers are not appropriate. The overall productivity factor showed that high-tech production depends mainly on improving technical efficiency, while the R\&D sector relies on advanced technology (Baia, Yanb and Chiu 2015).

In addition to investing in $R \& D$, some other factors are also important for high-tech companies and the rise from the crisis. In China (Wanga and Lestaria 2013), a study was conducted on the effects of three entrepreneurial competencies on the effective market entry of high-tech companies from emerging markets, namely business networks, new product development and marketing management. They found that marketing alone directly affects the success and market entry, while the other two competencies have no indirect effects. The research also showed the important role of the business network as a prerequisite for the entry process, and at the same time, the development 
of new products serves as a driving force of marketing by creating competitive products (ibid.).

Venture capital has also proved to be an important factor for the high-tech sector. A sample of 128 companies (Bertonia, Croceb and Guerinib 2015) that were supported by venture capital and 233 companies that did not receive venture capital was surveyed on how and when venture capital alleviates the financial constraints of portfolio companies. The findings show that venture capital regulates the investment curves of companies, which also means a reduction in financial constraints. This effect is economically and statistically significant only when the company moves into the next round of venture capital financing. These follow-up funding rounds do not, on average, involve larger investment amounts, but have stronger information content than initial investment rounds. Evidence regarding corporate access to venture capital loans confirms this interpretation of the results (Bertonia, Croceb and Guerinib 2015).

Venture capital investments can come from a variety of sources. A 2014 survey (see Grilli and Murtinu 2014) assessed the impact of state-managed venture capital and private venture capital on sales and employment growth in European high-tech companies. The results show that the main, statistically robust and economically significant positive effect on sales growth is related to private investors. In contrast, the impact of investment by the state appears to be negligible. A positive and statistically significant impact of consortium investments of both types of investors on sales growth was also found, but only in the case where the main investor was private. Overall, the survey casts doubt on the ability of governments to support high-tech companies through direct and active participation in the venture capital market (Grilli and Murtinu 2014).

As an example of good practice, we can once again highlight Israel. From the perspective of start-ups (Wonglimpiyarat 2016), Israeli Silicon Wadi ${ }^{2}$ ranks immediately behind American Silicon Valley. As already mentioned, Israeli state policy has an important role to play in fostering innovation and guiding the country towards a high-tech driving force. The success of hightech clusters is a result of government policy and investment in venture capital programs. Also important in this was the fact that it did not exclude government funding but attracted a mass of private investors. Israel is an interesting example of the most successful economy modelled on Silicon Valley. The experience of the Israeli success story and the path to achieving

\footnotetext{
${ }^{2}$ Israeli Silicon Wadi is an area with a high concentration of high-tech industry in the coastal plain in Israel, similar to Silicon Valley in California, USA.
} 
the goal of becoming a high-tech driving force is also useful for other countries and the transfer of knowledge about the system of promoting high-tech clusters (Wonglimpiyarat 2016).

The economic crisis has also affected the high-tech sector. However, the above data and research show that the high-tech sector can have a way out of the crisis and, due to its positive impact on other sectors, as well as on GDP and employment, can be a key help in getting out of it. In addition to the general state of the economy, investment, research, innovation, human capital and other factors, the state is also an important factor in the operation of the high-tech sector.

\section{Europe 2020 grand strategies towards active support of HTCs} Given the research, done by different researchers around the world, we could summarize, that $R \& D$ investments, Venture capital investments and knowledge are the three factors that influence the high-tech industries. Further on, with these assets, the high-tech industries influence the international trade, value of exports and employment to the extent that it can help the national economy in the time of economic crisis. Since the technological classification is very narrow and some sectors have a high share of R\&D and employ highly educated people one could argue, that the three mentioned factors can have a positive effect in all sectors and are generally important. In that manner, we scanned the EU grans strategies, not searching for specific addressing of high-tech industries but the three factors themselves. The most recent data available now is R\&D spending.

Already in 2010, the European Commission acknowledged: "R\&D spends less than $2 \%$ in Europe, compared to $2.6 \%$ in the US and $3.4 \%$ in Japan, mainly due to lower levels of private investment. It is not only the absolute amounts of investment in research and development that are important" (European Commission 2010). The Strategy for smart, sustainable and inclusive growth has set the bar of 3\% of the EU's GDP that should be invested in R\&D (see European Commission 2010).

To set specific focus, the European Commission published the European 2020 Flagship Initiative: "Innovation Union". Its aim is (European Commission 2011) to refocus R\&D and innovation policy on the challenges facing our society, such as climate change, energy and resource efficiency, health and demographic change. The document assured the possibility to the Commission to work on completion of the European Research Area by developing a strategic research agenda and to enhance joint programming with Member States and regions; improve framework conditions for business 
to innovate; launch 'European Innovation Partnerships' between the EU and national levels to speed up the development and deployment of the technologies needed to meet the challenges identified; strengthen and further develop the role of EU instruments to support innovation; promote knowledge partnerships and strengthen links between education, business, research and innovation, including through the EIT, and to promote entrepreneurship by supporting Young Innovative Companies (ibid.).

The clarification about the target was that it (see European Commission 2011) has succeeded in focusing attention on the need for both the public and private sectors to invest in R\&D but it focuses on input rather than impact. There is a clear need to improve the conditions for private $R \& D$ in the EU and many of the measures proposed in this strategy will do this (ibid.). As one can read further, the EC states that it is also clear (ibid.) that by looking at R\&D and innovation together we would get a broader range of expenditure, which would be more relevant for business operations and productivity drivers. The EC proposes to keep the 3\% target while developing an indicator, which would reflect $R \& D$ and innovation intensity (ibid.).

Graph 2: Gross domestic spending on R\&DTotal, \% of GDP, 2008-2018

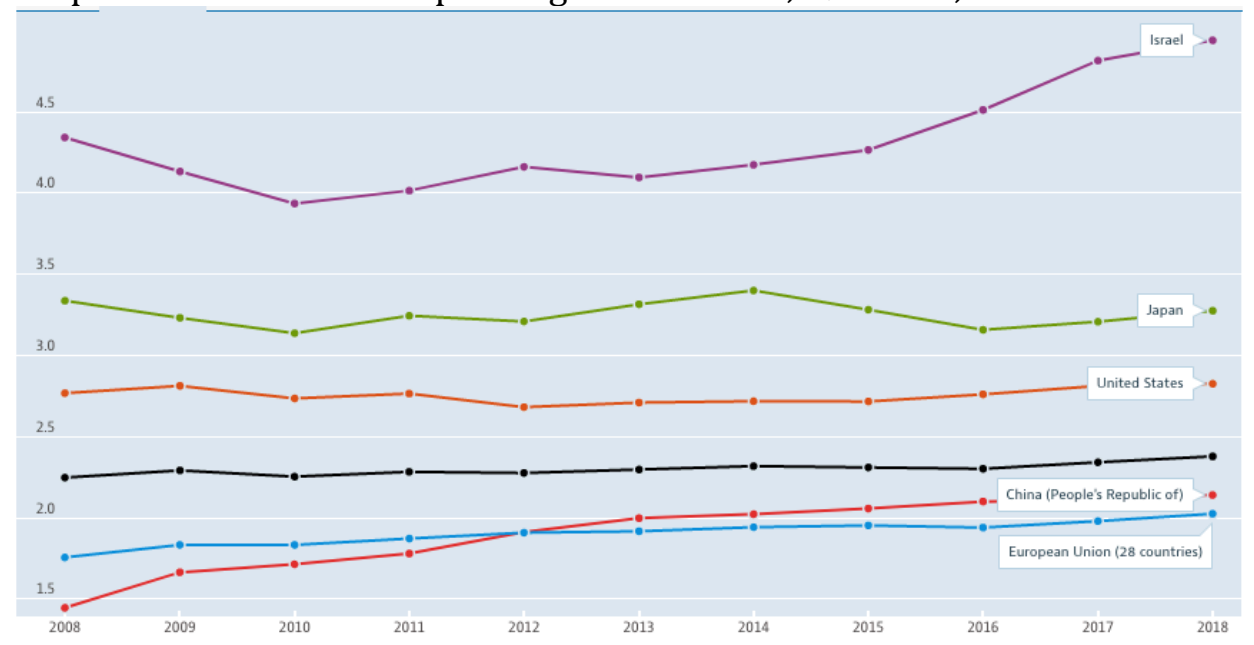

Source: OECD 2020

If we keep in mind, that there was an extensive world economic crisis, roughly between 2007 and 2009 (depending on the country or region it started before and/or finished after that year) we can see an interesting comparison between few selected countries. Mainly, all the countries are pushing up the $\%$ of $R \& D$ spending. What is more interesting and worrying from the EU 
perspective is a level of R\&D spending in EU countries, being the lowest from 2012 on. Even the OECD in total rises above the EU. The below graph is a visual display of the situation also raising the question of what does the $3 \%$ target mean? No one will be waiting for the EU to catch the train. In that manner, the $3 \%$ would mean the EU to stay in the game but not being in the big league, being the one who sets trends. Is it possible that the EU is not capable to reach higher than $3 \%$ ?

Table 2 shows the R\&D expenditure by all sectors of performance in EUR per inhabitant. The table was arranged based on the values of expenditure. $64 \%$ of the EU countries spend less than the Eu28 average for R\&D per inhabitant. The lowest expenditure (Romania 52,5 EUR) is only 3,3\% of the highest, being Denmark with 1580,9 EUR per inhabitant. The disproportions among the countries in the EU regarding the R\&D expenditure are, seem like, light years apart, calling for a more complex, extensive breakdown of how to level the member states. Mainly we could argue that there are member states with no fundamental prerequisites for business and research.

Table 2: R\&D expenditure (GERD) by sectors of performance, all sectors, Euro per inhabitant

\begin{tabular}{|l|r|}
\hline GEO/TIME & \multicolumn{1}{|r|}{2018} \\
\hline Romania & 52,5 \\
\hline Bulgaria & 60,1 \\
\hline Latvia & 96,3 \\
\hline Croatia & 122,2 \\
\hline Cyprus & 134 \\
\hline Slovakia & 138 \\
\hline Malta & 148,8 \\
\hline Lithuania & 151,8 \\
\hline Poland & 158,5 \\
\hline Greece & 202,5 \\
\hline Hungary & 209,8 \\
\hline Portugal & 269,1 \\
\hline Estonia & 277,2 \\
\hline Spain & 320,3 \\
\hline Czechia & 377,6 \\
\hline Italy & 406,4 \\
\hline Slovenia & 431,8 \\
\hline
\end{tabular}




\begin{tabular}{|l|r|} 
United Kingdom & 622,7 \\
\hline European Union 28 & 656,8 \\
\hline Ireland & 769,5 \\
France & 773,6 \\
\hline Netherlands & 974,8 \\
\hline Belgium & 1.115 \\
\hline Finland & $1.167,7$ \\
\hline Luxembourg & $1.208,3$ \\
\hline Germany & $1.266,3$ \\
\hline Austria & $1.388,1$ \\
\hline Sweden & $1.544,6$ \\
\hline Denmark & $1.580,9$ \\
\hline
\end{tabular}

Source: European Commission, EUROSTAT 2020

The same could be argued when examining the High technology exports as in $\%$ of manufactured exports (see Table 3). The EU reaches over $15 \%$ in 2018, but there are large differences between countries; from $32.21 \%$ in Malta to only $5.27 \%$ in Portugal. Comparing the EU to China, Israel and the USA one would argue, that the EU is lacking behind but again, as acknowledged before, the EU cannot be directly compared to them.

Table 3: High technology exports (\% of manufactured exports)

\begin{tabular}{|l|r|}
\hline Country Name & \multicolumn{2}{|l|}{ 2018 } \\
\hline Portugal & 6,27 \\
\hline Slovenia & 6,81 \\
\hline Luxembourg & 6,97 \\
\hline Italy & 7,51 \\
\hline Croatia & 8,89 \\
\hline Finland & 8,93 \\
\hline Romania & 10,08 \\
\hline Bulgaria & 10,27 \\
\hline Belgium & 10,37 \\
\hline Poland & 10,60 \\
\hline Slovak Republic & 10,63 \\
\hline Austria & 11,64 \\
\hline
\end{tabular}


45 | RSC Volume 12, Issue 3, September 2020

\begin{tabular}{|l|r|}
\hline Lithuania & 12,11 \\
\hline Greece & 12,81 \\
\hline Denmark & 13,89 \\
\hline Sweden & 14,36 \\
\hline European Union & 15,62 \\
\hline Germany & 15,78 \\
\hline Estonia & 16,84 \\
\hline Hungary & 16,94 \\
\hline Czech Republic & 19,63 \\
\hline Cyprus & 19,86 \\
\hline Latvia & 20,28 \\
\hline United Kingdom & 22,64 \\
\hline Netherlands & 22,68 \\
\hline Ireland & 24,68 \\
\hline France & 25,92 \\
\hline Malta & 32,21 \\
\hline
\end{tabular}

Source: World Development Indicators, Last Updated: 09/08/2020

The European Commission recognized the problem of significant differences (see European Commission 2011) and encourages the member states to offer a better Business environment by improving the business environment especially for innovative SMEs, including through public sector procurement to support innovation incentives; improving the conditions for enforcing intellectual property; reducing the administrative burden on companies, and improve the quality of business legislation; working closely with stakeholders in different sectors to identify bottlenecks and develop a shared analysis on how to maintain a strong industrial and knowledge base and put the EU in a position to lead global sustainable development (ibid.). Not to forget about the basic research, the member states were given guidelines by the European 2020 Flagship Initiative: "Innovation Union" to: reform national (and regional) $R \& D$ and innovation systems to foster excellence and smart specialisation, reinforce cooperation between universities, research and business, implement joint programming and enhance cross-border cooperation in areas with EU value-added and adjust national funding procedures accordingly, to ensure the diffusion of technology across the EU territory; ensure a sufficient supply of science, math and engineering 
graduates and to focus school curricula on creativity, innovation, and entrepreneurship; priorities knowledge expenditure, including by using tax incentives and other financial instruments to promote greater private $R \& D$ investments.

\section{What about the future?}

The Europe 2030 strategy (European Commission 2018) based on United Nations Sustainable Development Goals by 2030 set the key enablers for the transition towards a sustainable Europe by 2030. Among them are ones, that are in line with our basic link to the high-technological companies: education, training, science, technology, research, innovation and digitization (see (European Commission 2018). The EU and its Member States could focus on financing breakthrough and disruptive technologies and innovative companies that have the potential to become EU and global market leaders in the sustainability transition, as well as on the effective and timely uptake of these innovations (ibid.). The European Commission set so-called Key enabling technologies to invest in specific technologies to help the industry in Europe. EC acknowledges that fast and comprehensive changes in science and technology are transforming our economy, generating new markets and players. In that regard, Europe prioritizes research and innovation support: advanced manufacturing, advanced materials and nanomaterials, life-science technologies, micro/nano-electronics and photonics, artificial intelligence, security and connectivity (see Internet 1 ). There is no mentioning of high-tech industries, but there is a statement, that "these KETs drive innovation throughout the economy and cut across industries with a trend towards full convergence and integration." (see Internet 1). The path towards better innovation performance might include the usage and applicability of highperformance computing (Besednjak Valič 2019).

An important aspect for business $R \& D$ is also addressed The Commission acknowledges, that the EU and its Member States would also need to promote stronger links between researchers and business. EU research, development and innovation hubs and incubators are important to support sustainable development, not only in terms of business sustainability, but also in terms of environmental sustainability (Mileva Boshkosla et al. 2018; Fric et al. 2020; Džajič Uršič 2020) so researchers and businesses can meet, exchange best practices, and spur innovation. While large companies may have the means to develop their research activities in-house, this is often not the case for smalland medium-sized enterprises. Stronger and more direct links with the research community have the potential to bridge this gap (European 
Commission 2018) and additionally the role of regional development agencies as intermediary organisations (Roncevic and Besednjak Valič 2019) need to be explored further. Technology, innovation and knowledge are forces that will enable the EU and its member states to survive even souring the crisis and the European Commission is well aware of that. However, the rise of the R\&D expenditure along with knowledge transfer and \% of FDI is not an agile thing to arise from a split decision for the EU. It is a long-term outcome of the EU policies and EU member states actions. The European Commission offers good foundations in their documents and policies, but even the Commission has its limits. Member states have to rise to the idea of national political support and appropriate business culture. With the help of European funds and transnational networking and benchmarking, they can assure business and research prerequisites, such as healthy business environment, knowledge transfer, institutional support, infrastructure, etc. If the economy and support system does not have solid foundations, we cannot anticipate moving along sustainable growth, green and economy.

\section{References}

Adkisson, V. Richard. 2015. "State-by-state variations in high-tech employment through the great recession." The Social Science Journal 52: 348357.

http://www.sciencedirect.com/science/article/pii/S0362331914000871. Accessed 10. 9. 2020.

Adkisson, V. Richard, Saucedo, E. 2010. "Merchandise exports and job quality: Evidence from the states.” Economic Development Quarterly 24 (3): 231-242. http://edq.sagepub.com/content/24/3/231.short. Accessed 15. 9. 2020.

Baesu, Viorica, Claudiu Tiberiu Albulescu, Zoltan-Bela Farkas, Drăghici, Anca. 2015. "Determinants of the High-tech Sector Innovation Performance in the European Union: A Review." Procedia Technology. 8th International Conference Interdisciplinarity in Engineering, INTER-ENG 19: 371-378. http://www.sciencedirect.com/science/article/pii/S2212017315000547. Accessed 10. 9. 2020.

Baia, Xue-Jie, Wen-Kai Yanb, Chiu, Yung-Ho. 2015. “Performance evaluation of China's Hi-tech zones in the post financial crisis era - Analysis based on the dynamic network SBM model." China Economic Review 34: 122-134. 
http://www.sciencedirect.com/science/article/pii/S1043951X15000541. Accessed 3. 9. 2020.

Barkey, Patrick M., John Baldridge, Christina Henderson, Furniss, Shannon. 2015. “High Growth for High-Tech.” Montana Business Quarterly 53 (2): 2-9. http://web.b.ebscohost.com/ehost/pdfviewer/pdfviewer?sid=c23302d8fd91-4c4b-8262-2e07ab4d245d\%40sessionmgr112\&vid=1\&hid=116. Accessed 15. 9. 2020.

Berkmen, S. Pelin, Gaston Gelos, Robert Rennhack, Walsh, P. James. 2012. "The global financial crisis: Explaining cross-country differences in the output impact." Journal of International Money and Finance 31 (1): 42-59. http://www.sciencedirect.com/science/article/pii/S0261560611001550 Accessed 10. 9. 2020.

Berry, Orna, Grayeff, Yigal. 2009. "Emerging Markets: Israel's Technology Industry as an Economic Growth Engine." Communications of the ACM 52 (12): 25 27. $3 p$.

http://web.b.ebscohost.com/ehost/pdfviewer/pdfviewer?sid=ed42da8e$42 \mathrm{bb}-4555-927 \mathrm{~d}-30 \mathrm{dd} 26 \mathrm{ece} 06 \mathrm{e} \% 40$ sessionmgr110\&vid=1\&hid=116.

Accessed 10. 9. 2020.

Bertonia, Fabio, Annalisa Croceb, Guerinib, Massimiliano. 2015. "Venture capital and the investment curve of young high-tech companies." Journal of $\begin{array}{lllll}\text { Corporate } & \text { Finance } & \text { 35: } & 159 & -\end{array}$ http://www.sciencedirect.com/science/article/pii/S0929119915001030 Accessed 15. 9. 2020.

Besednjak Valič, Tamara. 2019. "Innovation, Digitalisation, and the HPC in the Danube Region." Edited by Borut Rončević, Coscodaru, Raluca, and Fric, Urška. Go with the Flow: High Performance Computing and Innovations in the Danube Region, 22-46.

Džajić Uršič, Erika. 2020. Morphogenesis of Industrial Symbiotic Networks. Berlin: Peter Lang. doi: 10.3726/b16330.

European Comission. 2010. Evropa 2020. Strategija za pametno, trajnostno in vključujočo rast. Bruselj, 3. 3. 2010. COM(2010) 2020. http://ec.europa.eu/eu2020/pdf/1 SL ACT part1 v1.pdf. Accessed 10. 9. 2020. 
49 | RSC Volume 12, Issue 3, September 2020

---- 2011. Europe 2020 Flagship Initiative Innovation Union. https://ec.europa.eu/research/innovation-union/pdf/innovation-unioncommunication-brochure en.pdf. Accessed 10. 9.2020.

--- 2018. Reflection paper towards a sustainable Europe by 2030. https://ec.europa.eu/commission/sites/betapolitical/files/factsheets sustainable europe 012019 v3.pdf. Accessed 20. 9. 2020.

European Commission. Eurostat. 2014. Eurostat indicators on High-tech industry and Knowledge - intensive services. http://statistica.regione.emiliaromagna.it/allegati/factbook 2014/eurostat-high-tech-aggregation-ofmanufacturing-and-services-nace-rev-2. Accessed 15. 9. 2020.

---. 2016. High-tech statistics. Last updated 23. 2. 2016. http://ec.europa.eu/eurostat/statistics-explained/index.php/Hightech statistics. Accessed 23. 2. 2016.

--- 2020. R\&D expenditure (GERD) by sectors of performance, All sectors, Euro per inhabitant. https://appsso.eurostat.ec.europa.eu/nui/show.do. Accessed 10. 9. 2020.

Fric, Urška, Rončević, Borut, Džajić Uršič, Erika. 2020. "Role of Computer Software Tools in Industrial Symbiotic Networks and the Examination of Sociocultural Factors. Environmental progress \& sustainable energy 39 (2): 17, doi: 10.1002/ep.13364.

Grilli, Luca, Samuele Murtinu. 2014. "Government venture capital and the growth of European high-tech entrepreneurial firms." Research Policy 43 (9): 1523

1543.

http://www.sciencedirect.com/science/article/pii/S0048733314000559. 2. 9. 2020 .

Hatzichronoglou, Thomas. 1997. Revision of the High-Technology Sector and Product Classification. OECD Science, Technology and Industry Working Papers, 1997/2.

Oecd

Publishing. http://search.oecd.org/officialdocuments/displaydocumentpdf/?cote=OCD E/GD\%2897\%29216\&docLanguage=En. 3. 9. 2020. 
Hsu, Wen-Hsin, Yao-Ling Chang. 2011. "Intellectual capital and analyst forecast: evidence from the high-tech industry in Taiwan." Applied Financial $\begin{array}{llll}\text { Economics } & 15: & 1135 & -\end{array}$ http://web.b.ebscohost.com/ehost/pdfviewer/pdfviewer?sid=40b739174e86-42aa-9f7d-e191ad2579dd\%40sessionmgr110\&vid=1\&hid=116. Accessed 2.9. 2020.

Internet 1: European Commission. Key enabling technologies policy. https://ec.europa.eu/info/research-and-innovation/researcharea/industrial-research-and-innovation/key-enabling-technologies en. Accessed 2. 9. 2020.

Karahan, Özcan. 2015 Intensity of Business Enterprise R\&D Expenditure and High-Tech Specification in European Manufacturing Sector. Procedia - Social and Behavioral Sciences World Conference on Technology, Innovation and Entrepreneurship 195: 806-813. http://www.sciencedirect.com/science/article/pii/S1877042815036599. Accessed 3. 9. 2020.

Kato, Masatoshi, Yuji Honjo. 2015. "Entrepreneurial human capital and the survival of new firms in high- and low-tech sectors." Journal of Evolutionary Economics 25

(5): 925-957. http://web.b.ebscohost.com/ehost/detail/detail?sid=b7675ac7-8db7-47aa$\underline{9 \mathrm{~d} 6 \mathrm{c}-}$

94d3fc11cc75\%40sessionmgr198\&vid $=0 \&$ hid $=116 \& b d a t a=I m x h b m c 9 c 2 \mathrm{w}$ mc210ZT1laG9zdC1saXZl\#AN=110951927\&db=buh. Accessed 3. 9. 2020.

Krishna, H. S., M. H. Subrahmanya Bala. 2015. "Transnational Entrepreneurship and Indian High-tech Start-up Survival: An Empirical Investigation." South Asian Journal of Management 22 (2): 81-98. http://web.b.ebscohost.com/ehost/pdfviewer/pdfviewer?sid=8b7c09faf5b0-4095-b33e-03de20eeabd7\%40sessionmgr112\&vid=1\&hid=116.

Accessed 2.9. 2020.

Makarovič, Matej, Šušteršič, Janez, Rončević, Borut. 2014. "Is Europe 2020 set to fail? The Cultural Political Economy of the EU Grand Strategies." European Planning Studies 22 (3): 610-626. 
Mileva Boshkoska, Biljana, Rončević, Borut, Džajić Uršič, Erika. 2018. "Modeling and evaluation of the possibilities of forming a regional industrial symbiosis networks". Social sciences 7 (1), doi: 10.3390/socsci7010013.

Morisson, Janet. 2002. The International Business Environment. New York: Palgrave.

Mrak, Mojmir, Rant, Vasja. 2011. "Vzroki svetovne finančne krize." Bančni vestnik (6): 2-8.

OECD. Main Science and Technology Indicators. https://data.oecd.org/rd/gross-domestic-spending-on-r-d.htm. Accessed 3. 9. 2020.

Rončević, Borut. 2019. "Cultural Political Economy of Europe 2020: Jean Monnet Chair CPE 2020 and its Impact." Research in Social Change 11 (2): 513.

Rončević, Borut, Besednjak Valič, Tamara. 2019. "How to Think about Regional Development Agencies as a Sociologist." The Social Sciences 14 (9): 326-34.

Sandua, Steliana, Ciocanel, Bogdan. 2014. "Impact of R\&D and Innovation on High-tech Export." Emerging Markets Queries in Finance and Business, Procedia Economics and Finance 15: 80-90. http://www.sciencedirect.com/science/article/pii/S221256711400450X. Accessed 5. 9. 2020.

Svetličič, Marjan. 2015. Zamujene razvojne priložnosti Slovenije. Ljubljana. Fakulteta za družbene vede.

Šipilova, Viktorija. 2015. "When Regional Growth Does Not Benefit from Hightech Specialization? Explaining the Experience of Latvian Regions." Procedia Economics and Finance 30: 863-875. http://www.sciencedirect.com/science/article/pii/S2212567115013362. Accessed 3. 3. 2016.

Štiblar, Franjo. 2008. Svetovna kriza in Slovenci: Kako jo preživeti? Ljubljana: Založba ZRC, ZRC SAZU. 
Tamar, Almor. 2011. "Dancing as fast as they can: Israeli high-tech firms and the Great Recession of 2008." Thunderbird International Business Review 53 (2):

195-208 http://web.b.ebscohost.com/ehost/detail/detail?sid=4e3c8929-8563-4bfaa58e-

$\underline{37 a c 8 c f 3 b f 17 \% 40 \text { sessionmgr } 112 \& \text { vid }=0 \& \text { hid }=116 \& \text { bdata }=I m x h b m c 9 c 2 \mathrm{wm}}$ c210ZT1laG9zdC1saXZl\#AN=58468076\&db=buh. Accessed 3. 9. 2020.

Tongbin, Zhang, Zhao Chi, Gong Ting, Ma Liyuan. 2015. "The Driving Effects and Conduction Paths of Chinese High-Tech Industry on National Economy." Journal of Applied Economics \& Business Research 5 (3): 130-147. http://web.b.ebscohost.com/ehost/detail/detail?sid=8a1a52b9-2482-4662$\underline{8 \mathrm{~b} 95-}$

06b58eeb28ce\%40sessionmgr112\&vid $=0$ \&hid $=116 \& b d a t a=I m x h b m c 9 c 2 w$ mc210ZT1laG9zdC1saXZl\#AN=110087202\&db=buh. Accessed 15. 9. 2020.

Wanga, David Han-Min, Tiffany Hui-Kuang Yub, Hong-Quan Liub. 2013. "Heterogeneous effect of high-tech industrial R\&D spending on economic growth." Journal of Business Research 66 (10): 1990-1993. http://www.sciencedirect.com/science/article/pii/S0148296313000477. Accessed 5. 9. 2020.

Wanga, Kung-Jeng, Yuliani Dwi Lestaria. 2013. "Firm competencies on market entry success: Evidence from a high-tech industry in an emerging market." Journal of Business Research 66 (12): 2444-2450. http://www.sciencedirect.com/science/article/pii/S0148296313002245 Accessed 15. 9. 2020.

Wonglimpiyarat, Jarunee. 2016. “Government policies towards Israel's hightech powerhouse." Technovation Available online 22 February 2016. http://www.sciencedirect.com/science/article/pii/S0166497216300049\#F CANote. 3. 9. 2020.

World Development Indicators. High-technology exports (\% of manufactured exports). Last Updated: 09/08/2020

https://databank.worldbank.org/reports.aspx?source=2\&series=TX.VAL.TE CH.MF.ZS\&country=EUU\#. 